\title{
The Digital Citizen
}

\subsection{INTRODUCTION}

New technology is changing the way in which individuals and societies communicate, learn, work and govern (Meyers et al., 2013). Digital citizens are described as 'those who use the internet regularly and effectively_that is, on a daily basis' (Mossberger et al., 2007, p. 1). Digital citizenship is not only the technical ability to participate online but to behave in an appropriate, responsible way with regard to such digital technology use (Mossberger et al., 2007; Ribble \& Bailey, 2007). Such regular, appropriate and responsible use implies a level of technical competence and digital literacy skills, as well as access to both technology and to the internet. However, the 'digital divide', representing 'the gap between individuals, households, businesses and geographic areas at different socio-economic levels with regard both to their opportunities to access information and communication technologies (ICTs) and to their use of the internet for a wide variety of activities' (OECD, 2001, p. 5), still persists due to the systemic inequalities that have emerged in societies worldwide (Beaunoyer et al., 2020). Evidence suggests that these inequalities are not only evident in developing economies, but also exist within richer economies, where significant disparities remain between urban centres and rural communities. Overcoming these inequalities requires equal emphasis on digital infrastructures and the development of digital skills. However, it is possible that the COVID-19 pandemic has served to widen rather than narrow this divide as more and more services are only available online and because access to workplaces, schools and libraries have been severely restricted, particularly in rural areas (Lai \& Widmar, 2021). At the same time, rural towns have become the preferred locations for many to live and

(C) The Author(s) 2022

T. Lynn et al., Digital Towns, https://doi.org/10.1007/978-3-030-91247-5_2 
work, presenting some optimism that previously struggling rural communities and economies can thrive in the future.

As discussed in Chap. 1, there are two important factors in the definition of towns-people and place. To paraphrase Marshall (1950, p. 149), to be a citizen is to be a member of a community. If digital citizenship is the ability to participate online then citizens must have the access, competences, and skills to use digital technologies. This chapter begins with a discussion on how and where digital inequalities, so-called 'digital divides', surface. It then discusses what digital literacy is and how competencies and skills might be categorised. Next, opportunities and challenges associated with remote and other new forms of work are considered. The final section discusses how extant international frameworks and composite indices measure access, competences, and use of digital technologies by individuals and households.

\subsection{The Digital Divide}

A significant proportion of the population worldwide either do not have access to the internet or the skills to leverage the opportunities presented by digital technologies. This is not limited to the developing world. In 2019, approximately 15\% of European households did not have internet access in 2019 citing insufficient skills (44\%), equipment costs (26\%) and high cost barriers (24\%) (Digital Economy and Skills Unit, 2020). This is consistent with findings from the OECD which suggests that $11.7 \%$ of adults aged 16 to 65 reported having no prior computer experience and a further $4.7 \%$ of adults did not possess basic ICT skills (OECD, 2019b).

As discussed in Chap. 1, the digital divide is a multi-faceted topic. It can be viewed across multiple levels including the availability of and access to technological infrastructure including computing equipment, software, and the internet, digital skills and use, and tangible outcomes of internet use (Scheerder et al., 2017; Philip et al., 2017; Wei et al., 2011). While the main focus of this book concerns bridging the urban-rural divide, rural communities, like their urban counterparts, may experience digital inequalities, typically related to age, income, education, and to a limited extent, gender. 


\subsubsection{The Grey Digital Divide}

Populations are ageing across developed economies worldwide (Rouzet et al., 2019). Economists anticipate that this will impact GDP per capita growth, labour market conditions, earnings, as well as potentially increasing inequality and poverty risk on future generations (Rouzet et al., 2019). Rural areas are not only, on average, older than urban areas but ageing is progressing faster in rural areas (OECD, 2019a). Furthermore, the ruralurban divide with respect to demographic profiles is expected to grow (Daniele et al., 2019).

Social isolation is defined as "a state in which the individual lacks a sense of belonging socially, lacks engagement with others, has a minimal number of social contacts and they are deficient in fulfilling and quality relationships" (Nicholson, 2009, p. 1346). While it may be a personal choice, where it is not so, individuals may experience loneliness (Havens et al., 2004). Social isolation and loneliness represent a substantial difficulty for older populations worldwide. They are associated with a variety of factors associated with poorer well-being and a lower quality of life (Murthy, 2020; Kaye, 2017; Havens et al., 2004). While research on rural and urban differences in social isolation and loneliness in older adults is mixed (Havens et al., 2004), older people in rural areas are impacted significantly from greater physical isolation and associated transportation issues (Kaye, 2017; Davidson \& Rossall, 2015).

Digital technologies can mitigate the negative outcomes of physical isolation, social isolation, and loneliness by connecting older adults to meaningful social network support provided they have access and the skills to use these technologies effectively (Francis et al., 2019). This sense of isolation was particularly exacerbated during the COVID-19 pandemic (Garcia et al., 2021), where the lack of ICT access, usage and skills among older populations became more apparent. In one recent study, increasing age was significantly and negatively associated with use of e-services (e.g., e-banking, e-government, e-health and e-learning) and social networking across the EU-28 (more so than education, gender or income) (ElenaBucea et al., 2020). As Friemel (2016, pp. 12-16) notes, the differences in internet use among those older than 70 years 'seems not to be linear but rather exponential'. Friemel notes that "with every additional year of age, the likelihood of usage decreases by $8 \%$ in five-year differences when considering a range of 65-90 years or more" (p. 328). 
The key determinants of using new technologies among older adults represent a combination of attitudinal, functional, and physical factors (Neves et al., 2018). Attitudinal factors include interest, anxiety (e.g., technophobia), perceived usefulness and perceptions of being too old to use it. Functional factors include access to devices, levels of education and digital skills, and ease of use depending on technology design and size. Finally, physical factors include limitations due to poor health or other age-related impairments such as visual acuity, reduced dexterity and memory. Access to education is regarded as an effective strategy in reducing social isolation among older people, as well as providing them with new knowledge and helping them to adapt to a changing society (Blažič \& Blažič, 2018).

\subsubsection{The Income Digital Divide}

Extant research suggests that an urban-rural income gap exists (Young, 2013). Level of income is regarded as a further reason for the digital divide (United Nations, 2012; World Bank, 2016) and is regarded as an important driver of the digital development of countries (Cruz-Jesus et al., 2017). Income, which impacts both internet access (Van Deursen et al., 2016) and usage (Robinson \& Williams, 2015; Zhang, 2013), was regarded as particularly important during the emergence of new technologies because owning a computer was regarded as an optional luxury (Lindblom \& Räsänen, 2017). In a study of 110 countries, Cruz-Jesus et al. (2017) found that 82.7 percent of the variance in the digital divide was explained by GDP alone. Other recent studies, however, show that lower income inequalities are associated with increased internet usage and mobile phone subscriptions, suggesting that the digital divide can be narrowed if income disparities reduce further (Richmond \& Triplett, 2018).

\subsubsection{The Education Digital Divide}

The use of ICT is sometimes complex, which is regarded as a significant obstacle to its adoption (Van Deursen et al., 2016). Pick and Azari (2008) report that government spending on education directly impacts access to ICT, which is positively related to ICT usage in both developed and developing countries. Recent evidence from across the EU-28 reports that education is strongly linked to the adoption of e-services and social networking (Elena-Bucea et al., 2020). Compared to age, gender or income, education 
was the strongest driver of the adoption of e-services. Van Deursen et al. (2016) also found that more educated respondents were consistently more confident about all dimensions of internet skills. In addition, competency in the English language represents a further barrier to access and usage (United Nations, 2012), as well as to decent prospects for future employment and life opportunities (Pick \& Nishida, 2015). Because digital exclusion has broader implications for accessing education, work and other opportunities, this creates what is termed the 'digital vicious cycle' (Baum et al., 2014). Education will be discussed in greater detail in Chap. 7 .

\subsubsection{The Gender Digital Divide}

Dixon et al. (2014) suggest that 'the phenomenon of technology itself cannot be fully understood without reference to gender' (p. 993). Differences in gender equality across nations reflect complex familial, institutional, religious, societal and stereotypical beliefs, which can also impact ICT access and usage (Cooper, 2006). Despite this complexity, the 'Women in Digital' scoreboard (European Commission, 2020b) suggests relative parity between men and women regarding the 'use of internet' across most EU states. This declines slightly with regard to internet skills among women compared to men. It further declines regarding 'specialist skills and employment'; a finding which reflects the lack of female participation in science, technology, engineering and mathematics (STEM) and ICT occupations. In their analysis across the EU-28, Elena-Bucea et al. (2020) found no evidence to suggest differences in levels of adoption between the genders. Van Deursen et al. (2016), however, found that men rated their skills consistently higher than females, with the exception of 'information navigation skills'. This finding perhaps reflects the so-called 'confidence gap', which has been reported across a range of studies on gender differences (Guillen, 2018).

\subsubsection{The Digital Divide and Other Vulnerable Parts of Society}

In addition to older adults, the vulnerable in society include a wide range of people including minors, disabled people, persons with serious illnesses or mental disorders, amongst others (European Commission, 2021). Vulnerable people are typically more likely to suffer from social exclusion and social isolation than the general population. The consequences of social exclusion can result in lower social and civic participation and 
representation, lower social standing, poverty, low human capital endowments, restricted access to employment and services (Tangcharoensathien et al., 2018). Digital participation may benefit vulnerable people by avoiding or mitigating the effects of social isolation, reducing stigma, and allowing these people to perform activities that are unavailable to them (Dobranski \& Hargittai, 2006; Duplaga, 2017). Unfortunately, there is evidence of digital divides for many vulnerable populations. For example, studies have found evidence of a disability digital divide in the UK (Office of National Statistics, 2019), Poland (Duplaga, 2017), Sweden (Johansson et al., 2021), amongst others (Kim et al., 2018; Tuikka et al., 2018). Similarly, digital divides have been found amongst refugees, displaced persons, and specifically asylum-related migrants (Merisalo \& Jauhiainen, 2020; Lynn et al., 2021). It is worth noting that inequalities can exist in those parts of society we assume are digitally native. While minors often have physical access to digital technologies, inequalities may exist with respect to mediation and contextualisation of use (Talaee \& Noroozi, 2019; Smahel et al., 2020). Talaee and Noroozi (2019) call for a reconceptualization of how we think about the digital divide with respect to children. They argue that access to a supportive 'social envelope', for example active mediation by parents and other family members, is the area in which most digital inequalities exist rather than the physical access to the hardware or even usage time. If a true measure of any society can be found in how it treats its most vulnerable members then digital initiatives and associated measurement frameworks must include those at most risk.

\subsection{Digital Literacy}

Globally, the lack of progress in the development of digital skills has been associated with difficulties in defining and measuring digital literacy (Van Deursen et al., 2016). While historically, the digital literacy literature has focussed on the prevalence and sophistication of (i) computer skills and (ii) internet skills (Hargittai, 2005), recent conceptualisations are more nuanced seeking to differentiate, between digital knowledge, skills and competencies (Iordache et al., 2017). Unfortunately, these nuances are not widely understood or applied, and as such are often conflated and used synonymously. Based on a review of 13 digital literacy models, Iordache et al. (2017) attempt to unravel these concepts into a practical set of interlinking definitions as per Table 2.1.

While there are a wide range of digital literacy models in the literature, there is significant commonality over the high-level categories of skills and 
Table 2.1 Definitions of digital knowledge, skills, competence, and literacy (Iordache et al., 2017)

\begin{tabular}{|c|c|}
\hline Term & Definition \\
\hline $\begin{array}{l}\text { Digital } \\
\text { knowledge }\end{array}$ & $\begin{array}{l}\text { Digital knowledge is the information, awareness, and understanding that } \\
\text { users have of the existence and usage of different digital tools. }\end{array}$ \\
\hline Digital skills & $\begin{array}{l}\text { Digital skills are practical, measurable applications of certain knowledge } \\
\text { or aptitudes in digital usage. }\end{array}$ \\
\hline $\begin{array}{l}\text { Digital } \\
\text { competence }\end{array}$ & $\begin{array}{l}\text { Digital competence is the ability to apply digital knowledge and skills to } \\
\text { various life contexts, from personal to professional. }\end{array}$ \\
\hline Digital literacy & $\begin{array}{l}\text { Digital literacy compiles the awareness, practical skills, and competences } \\
\text { necessary for users to access, understand, evaluate, } \\
\text { communicate with others, and create digital content in a strategic and } \\
\text { applied manner, towards the fulfilment of personal and professional } \\
\text { goals. }\end{array}$ \\
\hline
\end{tabular}

Table 2.2 Categories of digital skills and competences (Iordache et al., 2017)

\begin{tabular}{|c|c|}
\hline Category & Exemplar skills and competences \\
\hline $\begin{array}{l}\text { Operational, technical and } \\
\text { formal }\end{array}$ & $\begin{array}{l}\text { - Using computer hardware and internet software } \\
\text { - Handling digital structures } \\
\text { Data privacy and protection }\end{array}$ \\
\hline Information and cognition & $\begin{array}{l}\text { - Analysing and evaluating online information } \\
\text { - Managing data } \\
\text { Digital problem-solving }\end{array}$ \\
\hline Digital communication & $\begin{array}{l}\text { - Construct and understand digital messages } \\
\text { - Exchange messages and share content } \\
\text { - Participate in online communities and networks } \\
\text { - Netiquette }\end{array}$ \\
\hline Digital content creation & $\begin{array}{l}\text { - Create and edit new content } \\
\text { - Integrate and remix existing content } \\
\text { - Awareness of intellectual property rights }\end{array}$ \\
\hline Strategic & $\begin{array}{l}\text { - Use information towards personal and professional } \\
\text { goals } \\
\text { - Identify digital competence gaps }\end{array}$ \\
\hline
\end{tabular}

competences. Iordache et al. (2017) classify digital skills and competences into five categories, largely based on van Deursen et al. (2014), as per Table 2.2.

Care needs to be taken that digital literacy and digital citizenship are not viewed in isolation. The skills required to participate fully online 
depend on the specific tasks to be performed e.g., e-government, e-health, online learning etc. These are discussed in Sect. 2.5 below and subsequent chapters. Furthermore, individuals acquire and develop these competences and skills through informal, formal and nonformal means. The extent to which educational opportunities are provided to all members of a given community varies. While the formal education system has made significant strides to integrate digital technologies, such provision may not be uniform and may struggle to maintain pace with technological change. Similarly, depending on the size of a town, comprehensive nonformal education provision may not be comprehensive or exist at all.

\subsection{New Forms of Work and Rural Towns}

COVID-19 and associated public health measures resulted in a temporary transition to remote working. Recent studies suggest remote work and virtual meetings are likely to continue, albeit less intensely than at the pandemic's peak (OECD, 2020; McKinsey, 2021). There is some optimism that this increased acceptance of teleworking combined with lower cost of living will help reverse population trends and increase the sustainability of smaller and rural towns. In addition to remote working, the emergence of online platforms to support the sharing economy and gig economy, are providing new markets, income, and economic opportunities to individuals and households in rural communities.

\subsubsection{Remote Working}

Remote working is the partial or total substitution of technology for the daily commute to and from work. Remote working options include working from home, working from a regional office close to home, or using coworking spaces (Spinuzzi, 2012). The COVID-19 pandemic saw an unprecedented surge in the numbers of people working remotely, with reports of up to half of the entire EU workforce working from home (Eurofound, 2020). The reported benefits of remote working can be organised at three levels: (i) societal (e.g., less traffic congestion and lower air and noise pollution, better opportunities for the disabled); (ii) organisational (e.g., cost savings due to lower infrastructural costs); and (iii) individual (e.g., greater flexibility, job satisfaction, lower transport costs, work-balance etc.) (Bloom et al., 2015; Martin \& MacDonnell, 2012; Morganson et al., 2010). Research suggests that remote working can be 
community-friendly (Kamerade \& Burchell, 2004), that it can increase productivity and improve organisational performance (Martin \& MacDonnell, 2012), and is associated with greater work-family balance and less work-family conflict (e.g., $\mathrm{He} \& \mathrm{Hu}, 2015$ ). Furthermore, research suggests that those working remotely even half-time can save between $\$ 2000$ and $\$ 6800$ a year (Lister, 2010). For organisations, remote work also offers an opportunity to cut costs arising from the reduced need for office space and associated running costs (Popma, 2013; Bloom et al., 2015). It should be noted that remote working need not take place in the home but in remote working hubs. While there is renewed interest and support for remote working hubs and telecenters in rural communities as a result of COVID-19 (Tomaz et al., 2021; Department of Rural and Community Development, 2021), they are not necessarily predicated on digital strategies.

Gallardo and Whitacre (2018) note the lack of research examining the impact that remote work has on local economic indicators such as income. They theorise that if remote working leads to higher levels of worker satisfaction and productivity, these outcomes should in turn lead to higher levels of income. They propose that workers who work remotely in 'outside locations' potentially increase the number of jobs available for local residents, as well as for residents of nearby areas who may commute in. Their study reported a positive relationship between remote working and median household income, suggesting that it can have a positive impact on local area income. They conclude that the traditional economic development approach of industry attraction and geographic clustering fails to consider other strategies and that remote working has the potential to become a community economic development tactic. This suggests a need to modify existing industrial incentive systems to focus more on placing workers in remote jobs (Erard, 2016). This would offer opportunities to rural communities to attract both workers and customers, while continuing to promote existing attractions (e.g., natural amenities, housing costs), which would help to level the playing field between urban and rural economies (Gallardo, 2016b). Despite the many reported benefits of remote working, a number of drawbacks have been noted including the potential for greater social isolation, stress and burnout. (Golden et al., 2008) and increased mental health symptoms (Mann \& Holdsworth, 2003; Bloom et al. (2015). One report from the EU suggests that while remote working can afford some flexibility, autonomy and empowerment, there is also a risk of work intensification, increased stress, longer hours, and blurring 
of the boundaries between work and private life (Eurofound, 2015; Popma, 2013). Some EU countries including France and Ireland have already developed a code of practice on 'the right to disconnect' and the EU parliament is paving the way for the enactment of legislation on this issue.

Prior to the pandemic, Hynes (2016) noted a lack of interest and/or commitment from employers to more fully embrace opportunities for remote work. From an infrastructural perspective, he noted the poor quality of broadband and a lack of policy or regulation for remote work as further impediments. Gallardo (2016a) suggests that a remote work-friendly policy framework should: (i) make it easier for businesses to offer remote work through subsidies and tax credits, which help retain fast-growth companies that may otherwise leave due to lack of labour supply, (ii) modify existing workforce development programmes to be better aligned with remote work (e.g., self-motivation, self-management, teamwork and other soft skills), and (iii) improve broadband availability and access for remote workers through multiple tax credit mechanisms (e.g., subsidising monthly access costs). Increased rural digitalisation offers a potential win-win for firms seeking labour but also workers seeking improved quality of life.

\subsubsection{The Gig Economy}

The gig economy relates to the intermediation of labour typically via an online platform. Gig economy platforms are typically two-sided platforms that match workers with customers, those who require work done on a per-service basis (Schwellnus et al., 2019). They include a wide range of services including transportation (e.g., Uber), home delivery (e.g., Deliveroo), home cleaning and maintenance (e.g., Care.com), data processing and other crowd work (e.g., Fiverr.com and Amazon Mechanical Turk), amongst others (Schwellnus et al., 2019). The popularity of such gig economy platforms can be explained by their virtual nature and low barriers to entry (Huang et al., 2018; Lynn et al., 2021). Consequently, work is both location- and time-agnostic enabling flexible, temporary, adhoc working arrangements (Huang et al., 2018; Lynn et al., 2021). These attributes may have a positive impact on rural economies by absorbing unemployment shocks, resolving underemployment and unemployment, and as a consequence positively impact rural-to-urban occupational migration (Huang et al., 2018; Burtch et al., 2018). Gig economy work is not 
without drawbacks including competition from low-income countries, discomfort associated with working for strangers, and traditional drawbacks associated with freelance work e.g., lack of employment and retirement benefits (Huang et al., 2020; Lynn et al., 2021). While gig work not only provides work that fits the needs and capabilities of workers and overcomes the limitations of rurality, research suggests it does not necessarily value the expertise and experience of, for example, older workers (Cook et al., 2019).

\subsubsection{The Sharing Economy}

Bartering, renting, swapping and sharing equipment and space are long standing market behaviours in rural communities, typically performed with friends, families and neighbours. In recent years, digital technologies and online platforms have transformed and revitalised these activities by enabling such transactions between strangers in what is widely referred to as the 'sharing economy' (Puschmann \& Alt, 2016; Laurenti et al., 2019). Whereas the gig economy focuses on the intermediation of labour, the sharing economy involves "[...] consumers granting each other temporary access to under-utilized physical assets ("idle capacity"), possibly for money" (Frenken \& Schor, 2019, pp. 121-122). The sharing economy is disrupting and transforming a number of sectors, not least the short stay and holiday accommodation sector e.g., AirBnB and Couchsurfing. The gig economy shares many of the same benefits of the sharing economy for rural communities in terms of access to income-earning opportunities and employment (Dreyer et al., 2017). However in many cases it is less impacted by competition from low-income countries and has potential additional benefits in terms of environmental sustainability derived from the increased utilisation of resources (Mi \& Coffman, 2019). To date, short stay accommodation and associated direct, indirect and induced economic effects has been the primary focus of sharing economy research, and anecdotally activity, in smaller and rural towns. However, recent research suggests that the attitudinal changes the COVID-19 pandemic has wrought with respect to scarcity, community living, and online participation, provides substantial opportunities for rural communities to overcome their local challenges through socio-economic sharing in other sectors including retail sustainability and poverty prevention (Buheji, 2020). 


\subsection{Measuring Individual and Household Access and Use of Digital Technologies}

Unsurprisingly, given the central role citizens play in society, individual and household access and use of digital technologies is a significant feature of the majority of international frameworks and composite indices for measuring the evolution and development of the digital society and the digital economy. There are a number of common themes. These include access to broadband and the internet which we address in Chap. 6, use of digital technologies, and the prevalence and sophistication of digital competences and skills. As can be seen from sources cited in Table 2.3 and later in Chap. 7, there is significant overlap with these themes and those used for measuring the integration of digital technologies into formal and

Table 2.3 Common themes and selected international sources for digital technology access and use by individuals and households

\begin{tabular}{|c|c|c|}
\hline Themes & Description & Selected sources \\
\hline Access & $\begin{array}{l}\text { Availability and access to digital } \\
\text { technologies (incl. the internet) } \\
\text { by individuals and households. }\end{array}$ & $\begin{array}{l}\text { Eurostat, ITU, Partnership on } \\
\text { Measuring ICT for } \\
\text { Development, UNESCO } \\
\text { Institute for Statistics }\end{array}$ \\
\hline Enrolment & $\begin{array}{l}\text { Enrolment in ICT-related } \\
\text { courses or fields }\end{array}$ & $\begin{array}{l}\text { Eurostat, Partnership on } \\
\text { Measuring ICT for } \\
\text { Development, UNESCO } \\
\text { Institute for Statistics }\end{array}$ \\
\hline Employment & Employment in the ICT sector & $\begin{array}{l}\text { Eurostat, ILO Labour Force } \\
\text { Survey }\end{array}$ \\
\hline Equity & $\begin{array}{l}\text { Relative access to and use of } \\
\text { digital technologies by female } \\
\text { citizens and the relative } \\
\text { proportion of female ICT } \\
\text { graduates. }\end{array}$ & UNESCO Institute for Statistics \\
\hline $\begin{array}{l}\text { Digital competence, } \\
\text { self-efficacy and } \\
\text { skills of individuals }\end{array}$ & $\begin{array}{l}\text { Individual competence, } \\
\text { self-efficacy and skills using } \\
\text { different technologies and } \\
\text { performing related tasks. }\end{array}$ & $\begin{array}{l}\text { Eurostat, EU Survey of Schools: } \\
\text { ICT in Education, PIAAC, } \\
\text { PISA, TALIS }\end{array}$ \\
\hline Use & $\begin{array}{l}\text { Incidence, intensity and patterns } \\
\text { of digital technology use by } \\
\text { individuals. }\end{array}$ & $\begin{array}{l}\text { EU Survey of Schools: ICT in } \\
\text { Education, Partnership on } \\
\text { Measuring ICT for } \\
\text { Development, PIAAC, PISA, } \\
\text { TALIS }\end{array}$ \\
\hline
\end{tabular}


nonformal education. While equity data is widely collected, it is somewhat myopic focussing on gender balance rather than other potential targets of inequality e.g., older adults, people with disabilities, refugees and other displaced persons, amongst others.

Two significant themes in extant frameworks are digital competences and use of digital technologies in general and by activity. There are a number of different frameworks for assessing digital skills competences sometimes from the same organisation (e.g., the UNESCO Media and Information Literacy (MIL) Curriculum for Teachers (UNESCO, 2021) and the UNESCO Global Media and Information Literacy Assessment (GMIL) Framework (UNESCO, 2013), the European skills/competences, qualifications and occupations (ESCO) transversal ICT skills list (European Commission, 2020b), and the European e-Competence Framework(e-CF) (CEN, 2019). Even where the source may be from the same or related organisations, the definition and gradation of skills and use may vary. In this regard, the European Digital Competence Framework (DigComp 2.0) is useful in that not only does it seek to provide a high level conceptual digital competence framework that synthesises many existing frameworks, it provides a useful mapping with MIL, GMIL, ESCO, and e-CF frameworks (Carretero Gomez et al., 2017). Table 2.4 summarises DigComp 2.1; at the time of writing the consultation for DigComp 2.2 was underway. It is important to note that the extent to which these competences, in any comprehensive way, feature in international frameworks and composite indices for the digital society and the digital economy is limited.

ICT skills are included in a number of international frameworks, typically by type of activity gradated from basic to advanced (Digital Economy and Skills Unit, 2020; G20 Digital Economy Task Force (DETF), 2018; Partnership on Measuring ICT for Development (ITU, 2018). For example, Table 2.5 outlines the main ICT skills indicators for DESI, the data for which is sourced from the Eurostat Community survey on ICT usage in Households and by Individuals (Digital Economy and Skills Unit, 2020).

Regarding ICT use, and more specifically ICT use for digital activities, there is significant variation across frameworks and composite indices. As well as access to digital infrastructure (Chap. 6), and the use of digital technologies for accessing and interacting with government and health services (Chap. 3), working and conducting business (Chap. 4), and for formal and nonformal education (Chap. 7), a wide range of activities are used as indicators. For example, the Partnership on Measuring ICT for Development (ITU, 2016) includes a comprehensive list of activities: 
- Getting information about goods or services

- Seeking health information

- Making an appointment with a health practitioner via a website

- Getting information from general government organizations

- Interacting with general government organizations

- Sending or receiving e-mail

- Telephoning over the Internet/VoIP

- Participating in social networks

- Accessing chat sites, blogs, newsgroups or online discussions

- Purchasing or ordering goods or services

- Selling goods or services

- Using services related to travel or travel-related accommodation

- Internet banking (and financial services)

- Doing a formal online course (in any subject)

- Consulting wikis (Wikipedia etc.), online encyclopaedias or other websites for formal learning purposes

- Listening to web radio (either paid or free of charge)

- Watching web television (either paid or free of charge)

- Streaming or downloading images, movies, videos or music; playing or downloading games (either paid or free of charge)

- Downloading software or applications (includes patches and upgrades, either paid or free of charge)

- Reading or downloading online newspapers or magazines, electronic books (includes accessing news websites, either paid or free of charge; includes subscriptions to online news services)

- Looking for a job or sending/submitting a job application (includes searching specific web sites for a job; sending/submitting an application online)

- Participating in professional networks (including social networking sites)

- Managing personal/own homepage

- Uploading self/user-created content to a website to be shared (text, images, photos, videos, music, software, etc.)

- Blogging: maintaining or adding contents to a blog

- Posting opinions on civic or political issues via websites (blogs, social networks, etc.) that may be created by any individual or organization

- Taking part in online consultations or voting to define civic or political issues 
- Using storage space on the internet to save documents, pictures, music video or other files (including cloud storage)

- Using software run over the internet for editing text documents, spreadsheets or presentations

Not all international frameworks are as comprehensive. Digital Economy and Skills Unit (2020) employs three sub-dimensions-(i) internet (non-) users, (ii) online activities (news, music, videos and games, video on demand, video calls, social networks, and doing an online course), and (iii) transactions (banking, shopping, and selling). DESI also measures access to infrastructure and e-Government interactions separately in other dimensions (Table 2.6).

Table 2.4 DigComp 2.1 competence areas and competences (adapted from Carretero Gomez et al., 2017)

\begin{tabular}{|c|c|c|}
\hline \multirow{2}{*}{$\begin{array}{l}\text { Competence areas } \\
\begin{array}{l}\text { 1. Information and data } \\
\text { literacy }\end{array}\end{array}$} & \multicolumn{2}{|c|}{ Competences } \\
\hline & 1.1 & $\begin{array}{l}\text { Browsing, searching and filtering data, information } \\
\text { and digital content }\end{array}$ \\
\hline & 1.2 & Evaluating data, information and digital content \\
\hline & 1.3 & Managing data, information and digital content \\
\hline \multirow{6}{*}{$\begin{array}{l}\text { 2. Communication and } \\
\text { collaboration }\end{array}$} & 2.1 & Interacting through digital technologies \\
\hline & 2.2 & Sharing through digital technologies \\
\hline & 2.3 & $\begin{array}{l}\text { Engaging in citizenship through digital } \\
\text { technologies }\end{array}$ \\
\hline & 2.4 & Collaborating through digital technologies \\
\hline & 2.5 & Netiquette \\
\hline & 2.6 & Managing digital identity \\
\hline \multirow[t]{4}{*}{ 3. Digital content creation } & 3.1 & Developing digital content \\
\hline & 3.2 & Integrating and re-elaborating digital content \\
\hline & 3.3 & Copyright and licences \\
\hline & 3.4 & Programming \\
\hline \multirow[t]{4}{*}{ 4. Safety } & 4.1 & Protecting devices \\
\hline & 4.2 & Protecting personal data and privacy \\
\hline & 4.3 & Protecting health and well-being \\
\hline & 4.4 & Protecting the environment \\
\hline \multirow[t]{4}{*}{ 5. Problem solving } & 5.1 & Solving technical problems \\
\hline & 5.2 & Identifying needs and technological responses \\
\hline & 5.3 & Creatively using digital technologies \\
\hline & 5.4 & Identifying digital competence gaps \\
\hline
\end{tabular}


Table 2.5 Digital skills indicators used in the EU Digital Economy and Society Index (Digital Economy and Skills Unit, 2020)

\begin{tabular}{ll}
\hline Indicator & Description \\
\hline $\begin{array}{l}\text { At least basic } \\
\text { digital skills }\end{array}$ & $\begin{array}{l}\text { Individuals with 'basic' or 'above basic' digital skills in each of the } \\
\text { following four dimensions: information, communication, problem solving } \\
\text { and software for content creation (as measured by the number of activities } \\
\text { carried out during the previous } 3 \text { months }\end{array}$ \\
$\begin{array}{ll}\text { Above basic } \\
\text { digital skills }\end{array}$ & $\begin{array}{l}\text { Individuals with 'above basic' digital skills in each of the following four } \\
\text { dimensions: information, communication, problem solving and software } \\
\text { for content creation (as measured by the number of activities carried out } \\
\text { during the previous } 3 \text { months). }\end{array}$ \\
$\begin{array}{l}\text { At least basic } \\
\text { software } \\
\text { skills }\end{array}$ & $\begin{array}{l}\text { Individuals who, in addition to having used basic software features such as } \\
\text { presentation or document integrating text, pictures and tables or charts, } \\
\text { or written code in a programming language. }\end{array}$ \\
&
\end{tabular}

Extant international frameworks for measuring the evolution and development of digital society and the digital economy, can also be distinguished by the extent to which they focus on individuals and households as opposed to society or an economy as a whole. For example, the Digital Capital Index and the IMD-SUTD Smart City Index exclusively focus on the perceptions of individuals, whereas as others, for example, the EU Digital Economy and Society Index (DESI), the G20 Toolkit for Measuring the Digital Economy, and Partnership on Measuring ICT for Development focus on a variety range of indicators including businesses and government.

While one would not expect the presence of remote working hubs in a set of digital indicators, it may be a proxy for a type of online work. New places of work and ways of working are typically under-represented or absent from commonly cited international frameworks. Similarly, uses of digital technologies associated with online work, the gig economy, and sharing economy have not featured prominently to date. In response to the increased prevalence of such practices during the COVID-19 pandemic, one would anticipate that this is likely to change.

As a final note, it is important to note that collecting data on those parts of society that do not use the internet or digital technologies is a substantial challenge. By definition, more modern methods of data collection such as online survey panels will not capture these cohorts thereby requiring on-site manual data collection from people who may be difficult to identify. 
Table 2.6 Selected indicators on digital technology skills and use by individuals and households in selected international digital society and digital economy measurement frameworks and composite indices excluding general access to digital infrastructure

\begin{tabular}{|c|c|c|}
\hline Framework & Description & Source \\
\hline $\begin{array}{l}\text { Digital } \\
\text { Economy \& } \\
\text { Society Index } \\
\text { (DESI) }\end{array}$ & $\begin{array}{l}\text { - Human Capital } \\
\text { - } \text { Digital skills } \\
\text { - Advanced skills and development } \\
\text { - Use of Internet Services } \\
\text { - } \text { Internet use } \\
\text { - } \text { Activities online } \\
\text { - Public Services } \\
\text { - } \quad \text { eGovernment users }\end{array}$ & $\begin{array}{l}\text { Digital } \\
\text { Economy and } \\
\text { Skills Unit } \\
(2020)\end{array}$ \\
\hline $\begin{array}{l}\text { Digital Capital } \\
\text { Index }\end{array}$ & $\begin{array}{l}\text { - } \text { Digital Access } \\
\text { - Support and training } \\
\text { - } \text { Digital Competence }\end{array}$ & $\begin{array}{l}\text { Ragnedda et al. } \\
(2020)\end{array}$ \\
\hline $\begin{array}{l}\text { Digital } \\
\text { Ecosystem } \\
\text { Development } \\
\text { Index }\end{array}$ & $\begin{array}{l}\text { - Household Digitization } \\
\text { - Internet use } \\
\text { - Electronic government } \\
\text { - Electronic commerce } \\
\text { - Telemedicine } \\
\text { - OTTs (Video on Demand penetration) }\end{array}$ & $\begin{array}{l}\text { Katz et al. } \\
(2014) ; \text { Katz } \\
\text { and Callorda } \\
(2018)\end{array}$ \\
\hline $\begin{array}{l}\text { G20 Toolkit for } \\
\text { Measuring the } \\
\text { Digital } \\
\text { Economy }\end{array}$ & $\begin{array}{l}\text { - Empowering Society } \\
\text { - } \text { Internet users } \\
\text { - People's use of the internet } \\
\text { - E-consumers } \\
\text { - } \text { Mobile money } \\
\text { - Citizen interacting with government via the } \\
\text { - STEM higher education } \\
\text { - Individuals with ICT skills }\end{array}$ & $\begin{array}{l}\text { G20 Digital } \\
\text { Economy Task } \\
\text { Force (DETF) } \\
(2018)\end{array}$ \\
\hline $\begin{array}{l}\text { ICT } \\
\text { Development } \\
\text { Index }\end{array}$ & $\begin{array}{l}\text { - ICT Use } \\
\text { - Percentage of individuals using the internet } \\
\text { - ICT Skills } \\
\text { - Percentage of individuals with ICT skills }\end{array}$ & $\begin{array}{l}\text { ITU }(2020, \\
2021)\end{array}$ \\
\hline $\begin{array}{l}\text { Partnership on } \\
\text { Measuring ICT } \\
\text { for } \\
\text { Development }\end{array}$ & $\begin{array}{l}\text { - Proportion of individuals using the internet } \\
\text { - By location } \\
\text { - By type of activity (see above) } \\
\text { - } \text { Individuals with ICT skills, by type of ICT skills } \\
\text { - Household expenditure on ICT } \\
\text { - Proportion of individuals not using the internet, } \\
\text { by type of reason }\end{array}$ & ITU (2016) \\
\hline
\end{tabular}




\subsection{Conclusion}

This chapter has identified many of the key challenges and opportunities for greater participation by individuals and households in a digital society. It considers a range of factors related to accessibility, affordability, and skills as key challenges. While new forms of work and working present opportunities for many living in rural communities, it is critical that those most vulnerable in society are not left behind in the digital society or digital economy. In measuring the evolution and development of digital progress in any community, whether a rural town, a city, or nation, only by understanding the extent of digital inequality can we take action to eradicate it.

\section{REFERENCES}

Baum, F., Newman, L., \& Biedrzycki, K. (2014). Vicious cycles: Digital technologies and determinants of health in Australia. Health Promotion International, 29(2), 349-360.

Beaunoyer, E., Dupérré, S., \& Guitton, M. J. (2020). COVID-19 and digital inequalities: Reciprocal impacts and mitigation strategies. Computers in Human Behavior, 111, 106424.

Blažič, A. J., \& Blažič, B. J. (2018). Digital skills for elderly people: A learning experiment in four European countries. Review of European Studies, $10(4), 74-86$.

Bloom, N., Liang, J., Roberts, J., \& Ying, Z. (2015). Does working from home work? The Quarterly Journal of Economics, 130, 165-218.

Buheji, M. (2020). Sharing economy and communities attitudes after covid-19 pandemic-review of possible socio-economic opportunities. American Journal of Economics, 10(6), 395-406.

Burtch, G., Carnahan, S., \& Greenwood, B. N. (2018). Can you gig it? An empirical examination of the gig economy and entrepreneurial activity. Management Science, 64(12), 5497-5520.

Carretero Gomez, S., Vuorikari, R., \& Punie, Y. (2017). DigComp 2.1: The digital competence framework for citizens with eight proficiency levels and examples of use. EUR 28558 EN, Publications Office of the European Union, Luxembourg.

CEN. (2019). European e-Competence Framework (e-CF). https://www.ecompetences.eu/e-cf-overview/

Cook, C., Diamond, R., \& Oyer, P. (2019, May). Older workers and the gig economy. In AEA Papers and Proceedings (Vol. 109, pp. 372-376).

Cooper, J. (2006). The digital divide: The special case of gender. Journal of Computer Assisted Learning, 22(5), 320-334. 
Cruz-Jesus, F., Oliveira, T., Bacao, F., \& Irani, Z. (2017). Assessing the pattern between economic and digital development of countries. Information Systems Frontiers, 19(4), 835-854.

Daniele, F., Honiden, T., \& Lembcke, A. C. (2019). Ageing and productivity growth in OECD regions: Combatting the economic impact of ageing through productivity growth? OECD Regional Development Working Papers 2019/08. OECD.

Davidson, S., \& Rossall, P. (2015). Evidence review: Loneliness in later life. White Paper, 1-29. Age UK.

Department of Rural and Community Development. (2021). Our rural future: Minister Humphreys announces $€ 8.8$ million in funding under the Connected Hubs Scheme. https://www.gov.ie/en/press-release/a6253-our-ruralfuture-minister-humphreys-announces-88-million-in-funding-under-theconnected-hubs-scheme/

Digital Economy and Skills Unit. (2020). The digital economy and society index 2020 - Methodological note. https://digital-strategy.ec.europa.eu/en/ policies/desi

Dixon, L. J., Correa, T., Straubhaar, J., Covarrubias, L., Graber, D., Spence, J., \& Rojas, V. (2014). Gendered space: The digital divide between male and female users in internet public access sites. Journal of Computer-Mediated Communication, 19, 991-1009.

Dobranski, K., \& Hargittai, E. (2006). The disability divide in internet and use. Information, Communication and Society, 9, 309-311.

Dreyer, B., Lüdeke-Freund, F., Hamann, R., \& Faccer, K. (2017). Upsides and downsides of the sharing economy: Collaborative consumption business models' stakeholder value impacts and their relationship to context. Technological Forecasting and Social Change, 125, 87-104.

Duplaga, M. (2017). Digital divide among people with disabilities: Analysis of data from a nationwide study for determinants of Internet use and activities performed online. PloS One, 12(6), e0179825.

Elena-Bucea, A., Cruz-Jesus, F., Oliveira, T., et al. (2020). Assessing the role of age, education, gender and income on the digital divide: Evidence for the European Union. Information Systems Frontiers. https://doi.org/10.1007/ s10796-020-10012-9

Erard, M. (2016). Remote? That's no way to describe this work. http://www. nytimes.com/2016/06/19/jobs/remotethats-no-way-to-describe-this-work. html?_r=1

Eurofound. (2015). New forms of employment. Publications Office of the European Union, Luxembourg.

Eurofound. (2020). Living, working and COVID-19. COVID-19 series. Publications Office of the European Union, Luxembourg. 
European Commission. (2020b). Women in digital scoreboard 2020. https:// digital-strategy.ec.europa.eu/en/library/women-digital-scoreboard-2020

European Commission. (2021). Vulnerable person. https://ec.europa.eu/homeaffairs/what-we-do/networks/european_migration_network/glossary_ search/vulnerable-person_en

Francis, J., Ball, C., Kadylak, T., \& Cotten, S. R. (2019). Aging in the digital age: Conceptualizing technology adoption and digital inequalities. In Ageing and digital technology (pp. 35-49). Springer.

Frenken, K., \& Schor, J. (2019). Putting the sharing economy into perspective. In A research agenda for sustainable consumption governance. Edward Elgar Publishing.

Friemel, T. N. (2016). The digital divide has grown old: Determinants of a digital divide among seniors. New Media es Society, 18(2), 313-331.

G20 Digital Economy Task Force (DETF). (2018). G20 toolkit for measuring the digital economy. OECD. https://www.oecd.org/g20/summits/buenosaires/G20-Toolkit-for-measuring-digital-economy.pdf

Gallardo, R. (2016a). Work in place: A telework-friendly policy framework. Mississippi State University Extension. http://extension.msstate.edu/publications/publications/work-place-telework-friendly-policy-framework

Gallardo, R. (2016b). Responsive countryside: The digital age and rural communities. Mississippi State University Extension Service.

Gallardo, R., \& Whitacre, B. (2018). 21st Century economic development: Telework and its impact on local income. Regional Science Policy é Practice, 10, 103-123.

Garcia, K. R., Rodrigues, L., Pereira, L., Busse, G., Irbe, M., Almada, M., Christensen, C., Midão, L., Dias, I., Heery, D., Hardy, R., Quarta, B., Poulain, M. M., Bertram, M., Karnikowski, M., \& Costa, E. (2021). Improving the digital skills of older adults in a COVID-19 pandemic environment. Educational Gerontology, 47(5), 196-206.

Golden, T. D., Veiga, J. F., \& Dino, R. N. (2008). The impact of professional isolation on teleworker job performance and turnover intentions: Does time spent teleworking, interacting face-to-face, or having access to communicationenhancing technology matter? Journal of Applied Psychology, 93, 1412-1421.

Guillen, L. (2018). Is the confidence gap between men and women a myth? Harvard Business Review, March 26.

Hargittai, E. (2005). Survey measures of web-oriented digital literacy. Social Science Computer Review, 23(3), 371-379.

Havens, B., Hall, M., Sylvestre, G., \& Jivan, T. (2004). Social isolation and loneliness: Differences between older rural and urban Manitobans. Canadian Journal on Aging/la revue canadienne du vieillissement, 23(2), 129-140.

He, S. Y., \& Hu, L. (2015). Telecommuting, income, and out-of-home activities. Travel Behaviour and Society, 2, 131-147. 
Huang, N., Burtch, G., \& Pavlou, P. (2018). Local economic conditions and worker participation in the online gig economy.

Huang, N., Burtch, G., Hong, Y., \& Pavlou, P. A. (2020). Unemployment and worker participation in the gig economy: Evidence from an online labor market. Information Systems Research, 31(2), 431-448.

Hynes, M. (2016). Developing (tele)work? A multi-level sociotechnical perspective of telework in Ireland. Research in Transportation Economics, 57, 21-31.

Iordache, C., Mariën, I., \& Baelden, D. (2017). Developing digital skills and competences: A quick-scan analysis of 13 digital literacy models. Italian Journal of Sociology of Education, 9(1). https://doi.org/10.14658/pupj-ijse-2017-1-2

ITU. (2016). Core list of ICT indicators. ITU Publications.

ITU. (2018). Measuring the Information Society Report 2018. ITU Publications.

ITU. (2020). ICT development index 2020: A proposal. https://www.itu.int/en/ ITU-D/Statistics/Documents/events/egti2020/IDI2020_Background Document_20200903.pdf

ITU. (2021). The ICT development index (IDI): Conceptual framework and methodology. https://www.itu.int/en/ITU-D/Statistics/Pages/publications/ mis/methodology.aspx

Johansson, S., Gulliksen, J., \& Gustavsson, C. (2021). Disability digital divide: the use of the internet, smartphones, computers and tablets among people with disabilities in Sweden. Universal Access in the Information Society, 20(1), 105-120.

Kamerade, D., \& Burchell, B. (2004). Teleworking and participatory capital: Is teleworking an isolating or a community-friendly form of work. European Sociological Review, 20, 345-361.

Katz, R., \& Callorda, F. (2018). The economic contribution of broadband, digitization and ICT regulation. ITU Publications.

Katz, R., Koutroumpis, P., \& Callorda, F. M. (2014). Using a digitization index to measure the economic and social impact of digital agendas. Info.

Kaye, L. W. (2017). Older adults, rural living, and the escalating risk of social isolation. Public Policy \& Aging Report, 27(4), 139-144.

Kim, E. J., Yuan, Y., Liebschutz, J., Cabral, H., \& Kazis, L. (2018). Understanding the digital gap among us adults with disability: Cross-sectional analysis of the health information national trends survey 2013. JMIR Rehabilitation and Assistive Technologies, 5(1), e8783.

Lai, J., \& Widmar, N. O. (2021). Revisiting the digital divide in the COVID-19 era. Applied Economic Perspectives and Policy, 43(1), 458-464.

Laurenti, R., Singh, J., Cotrim, J. M., Toni, M., \& Sinha, R. (2019). Characterizing the sharing economy state of the research: A systematic map. Sustainability, $11(20), 5729$.

Lindblom, T., \& Räsänen, P. (2017). Between class and status? Examining the digital divide in Finland, the United Kingdom, and Greece. Information Society, $33(3), 147-158$. 
Lynn, T., Fowley, F., Fox, G., Endo, P. T., Rosati, P., \& Ogunsanya, L. (2021). Nanojobs: Towards an open crowd working platform for refugees and displaced persons. 2021 IEEE International Humanitarian Technology Conference (IEEE IHTC 2021).

Mann, S., \& Holdsworth, L. (2003). The psychological impact of teleworking: Stress, emotions and health. New Technology, Work, and Employment, $18,196-211$.

Marshall, T. H. (1950). Citizenship and social class (Vol. 11, pp. 28-29). Cambridge.

Martin, B. H., \& MacDonnell, R. (2012). Is telework effective for organizations? Management Research Review, 35(7), 602-616.

McKinsey. (2021). The future of work after COVID-19. https://www.mckinsey. com/featured-insights/future-of-work/the-future-of-work-after-covid-19

Merisalo, M., \& Jauhiainen, J. S. (2020). Digital divides among asylum-related migrants: Comparing internet use and smartphone ownership. Tijdschrift voor economische en sociale geografie, 111(5), 689-704.

Meyers, E. M., Erickson, I., \& Small, R. V. (2013). Digital literacy and informal learning environments: An introduction. Learning, Media \& Technology, $38(4), 355-367$.

Mi, Z., \& Coffman, D. M. (2019). The sharing economy promotes sustainable societies. Nature Communications, 10(1), 1-3.

Morganson, V. J., Major, D. A., Oborn, K. L., Verive, J. M., \& Heelan, M. P. (2010). Comparing telework locations and traditional work arrangements: Differences in work-life balance support, job satisfaction, and inclusion. Journal of Managerial Psychology, 25, 578-595.

Mossberger, K., Tolbert, C. J., \& McNeal, R. S. (2007). Digital citizenship: The internet, society and participation. MIT Press.

Murthy, V. (2020). Together: Loneliness, health and what happens when we find connection. Profile Books.

Neves, B. B., Waycott, J., \& Malta, S. (2018). Old and afraid of new communication technologies? Reconceptualising and contesting the 'age-based digital divide'. Journal of Sociology, 54(2), 236-248.

Nicholson, N. R. (2009). Social isolation in older adults: An evolutionary concept analysis. Journal of Advanced Nursing, 65(6), 1342-1352.

Office of National Statistics. (2019). Exploring the UK's digital divide. https:// www.ons.gov.uk/peoplepopulationandcommunity/householdcharacteristics / homeinternetandsocialmediausage/articles/exploringtheuksdigitaldivide/ 2019-03-04

OECD. (2001). Understanding the digital divide. OECD Digital Economy Papers, 49. OECD Publishing. https://doi.org/10.1787/236405667766

OECD. (2019a). OECD regional outlook 2019: Leveraging megatrends for cities and rural areas. 
OECD. (2019b). Skills matter: Additional results from the survey of adult skills. OECD Skills Studies. OECD Publishing. https://doi.org/10.1787/ lf029d8f-en

OECD. (2020). The territorial impact of COVID-19: Managing the crisis across levels of government. OECD Policy Responses to Coronavirus (COVID-19), OECD. https://www.oecd.org/coronavirus/policy-responses/the-territorial-impactof-covid-19-managing-the-crisis-across-levels-of-government-d3e314el/

Philip, L., Cottrill, C., Farrington, J., Williams, F., \& Ashmore, F. (2017). The digital divide: Patterns, policy and scenarios for connecting the 'final few' in rural communities across Great Britain. Journal of Rural Studies, 54, 386-398.

Pick, J. B., \& Azari, R. (2008). Global digital divide: Influence of socioeconomic, governmental and accessibility factor on information technology. Information Technology for Development, 14(2), 91-115.

Pick, J. B., \& Nishida, T. (2015). Digital divides in the world and its regions: A spatial and multivariate analysis of technological utilisation. Technological Forecasting and Social Change, 91(c), 1-17.

Popma, J. (2013). The Janus face of the 'New Ways of Work'. Rise, risks and regulation of nomadic work. ETUI, Working Paper 2013.07, Brussels.

Puschmann, T., \& Alt, R. (2016). Sharing economy. Business \& Information Systems Engineering, 58(1), 93-99.

Ragnedda, M., Ruiu, M. L., \& Addeo, F. (2020). Measuring digital capital: An empirical investigation. New Media es Society, 22(5), 793-816.

Ribble, M., \& Bailey, G. (2007). Digital citizenship in schools. ISTE.

Richmond, K., \& Triplett, R. E. (2018). ICT and income inequality: A crossnational perspective. International Review of Applied Economics, 32(2), 195-214.

Robinson, L., \& Williams, A. (2015). Where we've been and where we are going. Information, Communication \& Society, 18(5), 475-477.

Rouzet, D., Sánchez, A. C., Renault, T., \& Roehn, O. (2019). Fiscal challenges and inclusive growth in ageing societies. Economic Paper No. 27. OECD.

Scheerder, A., Van Deursen, A., \& Van Dijk, J. (2017). Determinants of Internet skills, uses and outcomes. A systematic review of the second-and third-level digital divide. Telematics and Informatics, 34(8), 1607-1624.

Schwellnus, C., Geva, A., Pak, M., \& Veiel, R. (2019). Gig economy platforms: Boon or Bane? OECD. https://www.oecd-ilibrary.org/docserver/fdb0570ben.pdf? expires $=1630150849 \&$ id $=$ id $\&$ accname $=$ guest $\&$ checksum $=67 \mathrm{D} 1394 \mathrm{~F}$ 5AlEBA29A1D760A09EB37D0F

Smahel, D., Machackova, H., Mascheroni, G., Dedkova, L., Staksrud, E., Ólafsson, K., Livingston, S., \& Hasebrink, U. (2020). EU kids online 2020: Survey results from 19 countries. 
Spinuzzi, C. (2012). Working alone together: Coworking as emergent collaborative activity. Journal of Business and Technical Communication, 26, 399-441. https://doi.org/10.1177/1050651912444070

Talaee, E., \& Noroozi, O. (2019). Re-conceptualization of “digital divide" among primary school children in an era of saturated access to technology. International Electronic Journal of Elementary Education, 12(1), 27-35.

Tangcharoensathien, V., Mills, A., Das, M. B., Patcharanarumol, W., Buntan, M., \& Johns, J. (2018). Addressing the health of vulnerable populations: Social inclusion and universal health coverage. Journal of Global Health, 8(2), 020304.

Tomaz, E., Moriset, B., \& Teller, J. (2021). Rural coworking spaces in the Covid-19 era. A window of opportunity?. https://halshs.archives-ouvertes.fr/halshs$03235464 /$ document

Tuikka, A. M., Vesala, H., \& Teittinen, A. (2018, September). Digital disability divide in Finland. In International conference on Well-being in the information society (pp. 162-173). Springer.

UNESCO. (2013). Global media and information literacy assessment framework: Country readiness and competencies. UNESCO.

UNESCO. (2021). Media and information literate citizens: Think critically, click wisely! (2nd ed.). UNESCO.

United Nations. (2012). E-Government survey: E-government for the people. United Nations. Retrieved July 13, 2021 , from https://publicadministration.un.org/ egovkb/Portals/egovkb/Documents/un/2012-Survey/unpan048065.pdf

Van Deursen, A.J.A.M., Helsper, E.J., \& Eynon, R. (2014). Measuring digital skills. From digital skills to tangible outcomes project report. www.oii.ox.ac.uk/ research/projects/?id=112

Van Deursen, A. J. A. M., Helsper, E. J., \& Enyon, R. (2016). Development and validation of the Internet Skills Scale (ISS). Information, Communication \& Society, 19(6), 804-823.

Wei, K. K., Teo, H. H., Chan, H. C., \& Tan, B. C. (2011). Conceptualizing and testing a social cognitive model of the digital divide. Information Systems Research, 22(1), 170-187.

World Bank Group. (2016). Evaluating digital citizen engagement: A practical guide. World Bank. License: CC BY 3.0 IGO. https://openknowledge.worldbank.org/handle/10986/23752

Young, A. (2013). Inequality, the urban-rural gap, and migration. The Quarterly Journal of Economics, 128(4), 1727-1785.

Zhang, W. (2013). Income disparity and digital divide: The internet consumption model and cross-country empirical research. Telecommunications Policy, $37(6-7), 515-529$. 
Open Access This chapter is licensed under the terms of the Creative Commons Attribution 4.0 International License (http://creativecommons.org/licenses/ by $/ 4.0 /$ ), which permits use, sharing, adaptation, distribution and reproduction in any medium or format, as long as you give appropriate credit to the original author(s) and the source, provide a link to the Creative Commons licence and indicate if changes were made.

The images or other third party material in this chapter are included in the chapter's Creative Commons licence, unless indicated otherwise in a credit line to the material. If material is not included in the chapter's Creative Commons licence and your intended use is not permitted by statutory regulation or exceeds the permitted use, you will need to obtain permission directly from the copyright holder. 